\title{
BENTUK, FUNGSI DAN MAKNA REDUPLIKASI PADA "KUMPULAN KISDAP BANJAR MALAM KUMPAI BATU"
}

\author{
Juwairiah
}

FKIP Universitas Lambung Mangkurat

Juwairiah_uwae@yahoo.com

\begin{abstract}
Abstrak
Reduplikasi adalalah pengulangan satuan gramatik, baik seluruh maupun sebagian, baik dengan variasi fonem maupun tidak. Dalam perkembangannya, reduplikasi sering ditemukan dalam sebuah novel atau cerpen yang bermacammacam jenisnya seperti salah satu "Kumpulan Kisdap Banjar Malam Kumpai batu" yang dijadikan objek penelitian dalam penelitian ini. Penelitian ini bertujuan untuk mengetahui bentuk,fungsi, dan makna reduplikasi kerena setiap cerita yang terdapat di dalamnya mengandung unsur-unsur budaya Banjar yang masih melekat hingga saat ini terdapat dalam buku yang dianalisis, metode dan pendekatan penelitian ini adalah metode deskriptif dan pendekatan kualitatif dengan teknik pengumpulan data yang digunakan adalah teknik dokumentasi yang berupa buku,majalah agenda dan lainnya.
\end{abstract}

Kata Kunci: reduplikasi, kisdap

\begin{abstract}
Abstrak
Reduplication is the repetition of grammatical units, either whole or in part, either with phonemic variations or not. In its development, reduplication is often found in a novel or short story of various kinds such as one of "Kisdap Banjar Malam Kumpai batu" which is used as the object of research in this research. This study aims to determine the form, function, and meaning reduplikasi because each story contained in it contains elements of Banjar culture that is still attached to this day is contained in the book analyzed, methods and approaches of this research is descriptive method and qualitative approach to the technique Data collection used is documentation techniques in the form of books, agenda magazines and others
\end{abstract}

Key words: reduplication, kisdap 


\section{Pendahuluan}

Bahasa merupakan alat komunikasi manusia dan sarana berinteraksi sesama yang paling utama. Melalui komunikasi, manusia dapat menyampaikan ide, gagasan, pengetahuan, dan perasaannya kepada sesama. Mulyono, ( 2013: 1) mengatakan batasan lain yang terkandung dalam Kamus Besar Bahasa Indonesia, bahwa morfologi adalah cabang linguistik tentang morfem dan kombinasikombinasinya. Secara popular, morfologi dibatasi dengan cabang ilmu bahasa yang mempelajari selukbeluk bentuk kata.

Dalam morfologi terjadi proses pembentukan kata seperti afiksasi, reduplikasi dan komposisi. Reduplikasi merupakan proses pembentukan kata dengan mengulang bentuk dasar, baik secara utuh maupun sebagian, dengan variasi fonem maupun tidak. (Ramlan,1987:63), Humaniora, (2008:93) dengan penelitian yang berjudul Herarki morfologi pada Verba Reduplikasi Bahasa Indonesia Tinjauan dari Prespektif Morfologi Derivasi dan Infleksi bahwa reduplikasi dalam bahasa Indonesia proses reduplikasi dari D anak $(\mathrm{N})$ menjadi anak-anak „balita merupakan reduplikasi derivasi, selain itu reduplikasi D pukul (verba transitif) menjadi pukul-memukul (verba transitif resiprokatif) merupaka reduplikasi derivasional. Selain itu menurut Chaer, (2007:182), reduplikasi merupakan proses merfenemis yang mengulang bentuk dasar, baik secara keseluruhan, sebagian, maupun bunyi

\section{Metode}

$\begin{array}{llr}\text { Metode kualitatif sebagai } & \text { yang } \\ \text { prusedur penelitian } & \text { yan }\end{array}$ menghasilkan datadeskriptif berupa kata-kata tertulis atau tulisan dari orang-orang dan perilaku yang diamati (Hikmah, 2014:37).

Metode Deskriptif yang paling sederhana dan banyak dilakukan oleh peneliti deskriptif. Tujuan utama menggunakan metode ini untuk menggambarkan sifat suatu keadaan yang sementara berjalan saat penelitian dilakukan dan memeriksa sebab-sebab dari suatu gejala tertentu (Travels, dalam Hikmah, 2014: 44). Berpendapat Gay (dalam Hikmah, 2014: 44) metode penelitian diskriptif adalah kegiatan yang meliputi pengumpulan data dalam rangka menguji hipotis atau menjawab pertanyaan yang menyangkut keadaan pada waktu yang sedang berjalan dari pokok suatu penelitian.

\section{Pembahasan}

Berdasarkan hasil penelitian yang dilakukan diperoleh berupa hasil penelitian sebagai berikut.

Mambawa kumpai-kumpai ilung wan kumpai batu

Kisdap di atas merupakan bentuk reduplikasi seluruh atau penuh karena merupakan kata ulang yang dibentuk dari pengulangan bentuk dasar secara utuh. Sama halnya dengan yang dipaparkan Jamzaroh (2010: 2) dengan penelitian yang berjudul Sistem Reduplikasi Bahasa Banjar (Sebuah Analisis Deskriptif) reduplikasi yang terjadi dari bentuk dasar yang diulang secara penuh, bentuk dasarnya berupa bentuk tunggal seperti kutipan diatas bentuk dasar 
kumpai (rumput) diulang menjadi kumpai-kumpai.

\section{Pual-pual lacit ka bantal}

Pual-pual lacit ka bantal pada paribahasa di atas merupakan bentuk kata ulang semu karena kata ulang semu menurut bentuknya tergolong kata ulang, tetapi sebenarnya bukan kata ulang sebab tidak ada dasar yang diulang

\section{Masi urang maulah laladuman}

Pada kisdap di atas merupakan bentuk redupliksasi dwipurwa bertambah imbuhan-an karena, pengulangan pada suku pertama yaitu la- bentuk dasarnya dari kata laladuman adalah ladum yang memiliki dua suku kata yaitu $l a$ dan dum kemudian ditambah lagi dengan imbuhan -an menjadi laladuaman.

Bilah kayu susumpal luang tagaian dicabut

Susumpal pada kisdap di atas merupakan bentuk dwipurwa karena pengulangan pada suku pertamnya yaitu su- bentuk dasarnya dari kata susumpal adalah sumpal yang memiliki dua suku kata yaitu sum dan pal sehingga menjadi susumpal.

Nurmala tabagun sambil mamusutmusut mata

Merupakan bentuk kata ulang sebagian, karena mamusut-musut bentukdasar yang diulang,baik kata dasar, kata berafiks, maupun kata majemuk, tidak seluruhnya diulang, melaikan hanya sebagian dari bentuk dasar tersebut.

Napang lawas-lawas banar kami kada suah badapat lagi

Fungsi reduplikasi yang terdapat pada kisdap napang lawaslawas banar kami kada suah badapat lagi adalah bentuk adverbia, karena merupakan keterangan keadaan.

Rapun-rapun rambai di pinggir sungai

Fungsi reduplikasi yang terdapat pada rapun-rapun rambai di pinggir sungai adalah reduplikasi nomina (kata benda), karena berarti dalam bahasa indonesia pohonpohon rambai di tepi sungai. Sama halnya dengan yang dipaparkan Ariyani (2012: 28) dengan penelitian yang berjudul Analisis pengulangan Reduplikasi pada Buku Cerita Anak Bergambar bahwa kata ulang diawali dengan kata lilin yang berupa kata benda tidak terjadi perubahan pada kata dasarnya tetapi kata dasar tersebut diulang lagi dibelakang kata ulang lilin- lilin yang mempunyai fungsi sebagai pembentuk kata benda yang bermakna banyak.

Sidin bujur-bujur bacabur manulungi kita badua

Fungsi reduplikasi yang terdapat pada kisdap sidin bujurbujur bacabur manulungi kita badua adalah Verba atau kata keterangan, karena bujur-bujur merupakan kata keterangan melakukan sesuatu.

Asa rami-rami ada jua mandangarakan

Fungsi reduplikasi pada kisdap asa rami-rami ada jua mandangarakan adalah bentuk adjektiva, karena rami-rami merupakan kata sifat yang menerangkan keadaan.

Napang lawas-lawas banar kami 
kada suah badapat lagi

Makna reduplikasi napang lawas-lawas banar kami kada suah badapat lagi adalah menyatakan menyangatkan karena kalimat napang lawas-lawas banar kami kada suah badapat lagi diartikan kedalam bahasa Indonesia adalah sudah lama sekali kami tidak berjumpa.

$\underline{\text { Rapun-rapun }}$ rambai di pinggir sungai

Makna reduplikasi rapunrapun rambai di pinggir sungai pada kisdap di atas adalah makna bermacam-macam,berjenis-jenis atau berbagai-bagai karena lebih dari satu rapun yang tumbuh di pinggir sungai.

Kada bamuha lagi kami wan kulakula dibanua

Makna reduplikasi pada kisdap di atas adalah banyak karena kalimat bilang asa kada bamuha lagi kami wan kula-kula di banua diartikan kedalam bahasa Indonesia adalah malu bertemu kelurga-kelurga yang ada didesa.

Sidin bujur- bujur bacabur manulungi kita badua

Makna reduplikasi sidin bujur- bujur bacabur manulungi kita badua adalah menyatakan penegasan karena kalimat sidin bujur-bujur bacabur manulungi kita badua diartikan kedalam bahasa Indonesia adalah menjelaskan beliau sungguhsungguh terjun membantu kita berdua.

\section{Pual-pual lacit ka bantal}

Makna reduplikasi pual-pual lacit $k a$ bantal adalah menyatakan berulang- ulang karena kalimat pual- pual lacit $\mathrm{ka}$ bantal diartikan kedalam bahasa Indonesia adalah berbekas-bekas mengenai bantal seperti yang kita ketahuai adalah kata berulang-ulang.

Dalam keadaan salau-salau ngitu,

Makna reduplikasi dalam keadaan salau-salau ngitu adalah menyatakan agak karena kalimat dalam keadaan salau-salau ngitu, kada singhaja kurus kurasaakan kami balihatan yang artinya dalam bahasa indonesia adalah saat keadaan remang-remang seperti melihat seseorang yang di kenal dan mereka saling berpandangan dalam kedaan yang tidak jelas.

\section{Masi urang maulah laladuman}

Makna masi urang maulah laladuman pada kisdap di atas adalah menyatakan makna menyerupai (tiruan) atau mirip karena jika kalimat maulah tagaian tutih sama banar lawan nang masi urang maulah laladuman diartikan kedalam bahasa Indonesia adalah bahwa tagaian mirip dengan domdoman bedanya domdoman di isi dengan minyak gas sedangkan tagaian di isi dengan air.

Kakawanan nang pina macal

Makna reduplikasi kakawanan nang pina macal pada paribahasa di atas adalah menyatakan sifat atau menyipati dari kata jamak, karena kata kakawanan nang pina macal jika di artikam kedalam bahasa Indonesia adalah temanteman yang nakal berarti jamak.

Bibinian ngitu takurihing

Makna reduplikasi bibinian 
ngitu takurihing adalah menyatakan kumpulan yang sejenis karena kalimat, bibinian ngitu takurihing diartikan kedalam bahasa Indonesia adalah perempuan itu terseyum.

\section{Simpulan}

Berdasarkan hasil penelitian, diperoleh simpulan sebagi berikut

1. Bentuk yang ditemukan dalam kumpulan kisdap terdiri 4 bentuk yaitu, (1) kata ulang utuh, (2) kata ulang semu, (3) dwipurwa dan dipurwa dikombinasikan dengan imbuha, (4) kata ulang sebagian.

2. Fungsi reduplikasi yang ditemukan, yakni ada 4 fungsi terdapat, (1) adverbia, (2) nomina, (3) verba, (4) adjektiva.

$3 . \quad$ Makna reduplikasi yang ditemukan, yakni terdapat 9 makna. (1) makna mengeraskan atau menyangatkan, (2) makna bermacam-macam, (3) makna jamak atau banyak, (4) menyatakan makna penegasan atau penekanan, (5) makna berulang-ulang, (6) makna agak,(7) makna menyerupai (tiruan) atau mirip, (8) kata sifat, (9) penekanan.

\section{Saran}

Penulis menyarankan jika ingin meneliti reduplikasi, sebaiknya meneliti reduplikasi yang berbeda dari penelitian sebelumnya dan memilih kajian atau objek yang lebih menarik untuk diteliti, selain menarik penulis menyarankan untuk memilih objek yang kaya informasi, bermakna, bermanfaat dan dapat menambah pengetahuan selain itu, penelitian ini diharapkan mampu menjadi alat pembanding bagi peneliti selanjutnya mengenai bagasa Banjar dan dapat dijadikan sebagai salah satu bahan pengajaran bahasa Indonesia untuk diajarkan kepada siswa-siswa, anak-anak, dan remaja.

\section{Daftar Rujukan}

Ariyani, Evi. 2011. Analisis Penggunaan Reduplikasi pada Buku Cerita Anak Bergambar. Skripsi pada FBS Universitas Negeri Yogyakarta: tidak diterbitkan.

Chaer, Abdul. 2007. Linguistik Umum. Jakarta: Rineka Cipta.

Hikmah, Mahi M. 2014. Metode Penelitian dalam Perspektif Ilmu Komunikasi dan Sastra. Yogyakarta : Graha Ilmu.

Humaniora, 2008. Herarki morfologi pada Verba Reduplikasi Bahasa Indonesia Tinjauan dari Prespektif Morfologi Derivasi dan Infleksi. Staf Pengajar Pakultas Bahasa, Sastra dan Seni, Universitas Negeri Padang. Volume 20, Nomor 1, Februari 2008.

Jamzaroh, Siti. 2010. Sistem Reduplikasi Bahasa Banjar, Sebuah Analisis Deskriptif. Balai Bahasa Banjarmasin. Volume 6, Nomor 1, Juni 2010.

Mulyono, Iyo. 2013. Ilmu Bahasa Indonesia Morfologi Teori dan Sejumput Problematik Terapannya. Bandung : $\mathrm{Cv}$ Yrama Widya.

Ramlan, M. 1987. Morfologi : Suatu Tinjauan Deskriptif. Edisi Revisi: Yogyakarta: CV. Karyono 